\title{
THE EFFECT OF ALLERGIC CONJUCTIVITIS ON CHOROIDAL THICKNESS
}

\author{
Ayyildiz Taha, ${ }^{1}$ Yilmaz Mevlut, ${ }^{2}$ Ayyildiz Didem ${ }^{3}$ \\ ${ }^{1}$ Kırsehir Ahi Evran University, Faculty of Medicine, Ophthalmology Department, Kırsehir, Turkey \\ ${ }^{2}$ Turkey Kursehir Ahi Evran University, Faculty of Medicine, Ophthalmology Department, Kirsehir, Turkey \\ ${ }^{3}$ Kursehir Ahi Evran University, Training and Research Hospital, \\ Child and Adolescent Psychiatry Department, Kursehir, Turkey
}

Primljen/Received 02. 08. 2019. god.

Abstract: Background: To examine the effects of allergic conjunctivitis and its treatment upon choroidal thickness (ChT) using topical antihistaminic agents.

Methods: 60 eyes of 30 children and adolescents with allergic conjunctivitis and 60 eyes of 30 healthy controls participated in the study. Inclusion criteria for patient groups were best-corrected visual acuity 20/20 or better, normal intraocular pressure (IOP) and no systemic or ocular diseases other than allergic conjunctivitis. Healthy controls recruited from children and adolescents who had no ocular or chronic systemic disorders and had best-corrected visual acuity 20/20 or better and normal IOP. ChT was measuredby using Enhanced Depth Imaging Optical Coherence Tomography (EDI-OCT) before and after treatment by antihistamine agents.

Results: Subfoveal choroidal thicknes mean value was $364.1 \pm 63.8 \mu \mathrm{m}$ in the allergic conjunctivitis group and the first-month values after the treatment were $333.5 \pm 52.1 \mu \mathrm{m}$. Subfoveal choroidal thickness means value in the control group was $320.6 \pm 80.9 \mu \mathrm{m}$. There was a statistically significant decrease in ChT after treatment of allergic conjunctivitis patients and there was a significant difference in terms of baseline ChT values between the allergic conjunctivitis group and the control group. There was no significant difference between one month after treatment values and the mean values of the control group.

Conclusions: Our results demonstrate that ChT can increase in allergic conjunctivitis patients and can become normal again with topical antihistamine treatment. In order to support choroidal thickness to be a marker for the diagnosis and follow-up of allergic conjunctivitis, further studies with larger samples and longitudinal studies are needed.
Prihvaćen/Accepted 01. 11. 2019. god.

Key words: Allergic conjunctivitis, Antihistamine, Choroidal thickness, Topical eyedrops, Treatment.

\section{INTRODUCTION}

Allergic conjunctivitis is one of the most common ocular disorders in pediatric patients and defined as a Type 1 hypersensitivity reaction in which the igE mediated response is involved. There are different types of allergic conjunctivitis such as acute, subacute allergic conjunctivitis, vernal and atopic keratoconjunctivitis. Acute allergic conjunctivitis is a common acute conjunctival reaction in children, which usually develops in spring and summer due to environmental allergens such as pollen (1).

The choroid is a highly vascularized layer of the eye formed of a dense capillary network and nourishes the deep, outer two-thirds of the retina. In a limited number of studies evaluating choroidal thickness (ChT) in children, there are contradictory results reporting that choroidal thickness increases (2) and decreases (3) in healthy children with age. In another study, subfoveal choroidal thickness was thinner in patients with myopia like those in adults $(4,5)$.

Studies revealed that choroidal thickness was increased in ocular pathologies particularly in central serous chorioretinopathy (CSCR). CSCR is an ophthalmic disease which characterized by pigment epithelial detachment in the neurosensory retina due to increased vascular permeability and hydrostatic pressure and is associated with an increase in choroidal thickness (6-9). In addition, increases in choroidal thickness in many inflammatory diseases with vascular involvement such as Juvenile Systemic Lupus Erythematosus (10), Crohn's Disease (11), Behçet's Disease (12) and 
Ankylosing Spondylitis (13) have been determined in previous studies.

Embryologically, eye and brain development are parallel to each other. The retina and the optic nerve are considered part of the central nervous system (CNS). Spectral Optical Coherence Tomography (SD-OCT) is a non-invasive imaging technique that enables in vivo visualization of the eye structures primarily used to monitor retinal changes in glaucoma (14). A method called enhanced depth imaging spectral-domain optical coherence tomography (EDI OCT) has been developed to make possible in vivo cross-sectional imaging of the choroid (15).

Since allergic conjunctivitis is a common inflammatory condition in children, we aimed to investigate the probable relationship between increased choroidal thickness and allergic conjunctivitis. We first aimed to examine whether ChT values showed differences between children and adolescents with allergic conjunctivitisand healthy controls. Our second aim was to investigate the effect of treatment by using topical antihistamine agents on ChT.

\section{METHOD}

\section{Sample}

The data obtained from the measurements of 60 eyes of 30 children and adolescents with allergic conjunctivitis (study group) and 60 eyes of 30 healthy controls (control group). Patients were admitted to the Ophthalmology outpatient clinic of Ahi Evran University Educational and Research Hospital in February-August 2017. Patients aged 9-17 years who have firstly diagnosed with acute allergic conjunctivitis and haven't received any treatment were included. Healthy controls who admitted to the Child Psychiatry outpatient clinic in the same hospital with minor psychological problems and had no ocular problems were recruited. Allergic conjunctivitis diagnosis was based on detailed history (episodic, seasonal, symptoms consist of itching, burning, watering) and ophthalmic examination by bio-microscope (papillary reaction in upper tarsal conjunctiva or stringy discharge). Patients with allergic conjunctivitis were given emedastine difumarate one drop two times daily after diagnosis and they were advised to stay away from an allergen. Subfoveal choroidal thickness measurements of the patients with allergic conjunctivitis were performed at the first examination and after 1-month than treatment.

\section{Procedure}

Children and adolescents with allergic conjunctivitis and healthy controls were evaluated by a special- ist in the outpatient clinic of Ophthalmology. Detailed ophthalmologic examination including visual acuity, intraocular pressure measurement was applied to all cases. Patients with visual acuity $\leq 20 / 20$ and any ocular or systemic disease diseases that might affect the choroidal thickness weren't included in the study. All patients who have allergic conjunctivitis underwent SD-OCT examination before and after one-month antihistamine treatment. Then the initial values were compared with one-month after treatment values. The initial and after one-month values were also compared with the control group values.

The research was carried out in accordance with Helsinki declaration rules and informed consent forms of patients were received.

\section{Oct Measurement}

Choroidal thickness was evaluated with SpectralDomain Optical Coherence Tomography (SD-OCT) (software version 6.3.3.0, Heidelberg Engineering Inc., Heidelberg, Germany). This device produces high-resolution images from low infrared light levels. The device contained a superluminescent diode with a wavelength of $870 \mathrm{~nm}$ and could obtain 40.000 A-scans per second. The axial and transverse resolutions were 7 and $14 \mu \mathrm{m}$, respectively. All examinations were performed between 9:00 a.m. and 12:00 noon, to avoid the effect of diurnal variation on choroidal thickness (16). These measurements were performed at the fovea on EDI-OCT mode which enables in vivo visualization of the choroid (17). Choroidal thickness measurements were performed in both eyes and the mean of the two measurements was evaluated.

\section{Statistical Analysis}

All statistical analyses were performed using Statistical Package for Social Sciences-SPSS for IBM, 20.0. Kolmogorov-Smirnov test was used to assess the normal distribution of continuous variables. ChT values after one-monthof topical antihistamine treatment were compared to the baseline using the paired test; after seeing that all of the continuous variables were normally distributed. The initial and one-month values were compared with the control groupby using student tests.The gender distribution of groups was evaluated by using the Chi-Square test. Statistical significance was accepted as $\mathrm{p}<0.05$.

\section{RESULTS}

Thirty children and adolescents with allergic conjunctivitis (17 boys and 13 girls) and 30 healthy controls (16 boys and 14 girls) were included in the study. 
Table 1. Demographics

\begin{tabular}{|lc|c|c|c|}
\hline & & Study group & Control group & p \\
\hline Gender $\mathrm{n}(\%)$ & $\begin{array}{l}\text { boy } \\
\text { girl }\end{array}$ & 17 & 16 & 0.74 \\
\hline Age mean (years) & 13 & $12 \pm 3.5$ & $11,5 \pm 4,1$ & 0.48 \\
\hline
\end{tabular}

Table 2. Subfoveal choroidal thickness value

\begin{tabular}{|c|c|c|c|c|}
\hline & $\begin{array}{c}\text { Allergic conjunctivitis } \\
\text { - no treatment } \\
\text { (Group 1) }\end{array}$ & $\begin{array}{c}\text { Allergic conjunctivitis } \\
\text { - Post treatment } \\
\text { (Group 2) }\end{array}$ & $\begin{array}{c}\text { Control group } \\
\text { (Group3) }\end{array}$ & P value \\
\hline $\begin{array}{c}\text { Subfoveal } \\
\text { Choroidal } \\
\text { Thickness (im) }\end{array}$ & $364.1 \pm 63.8$ & $333.5 \pm 52.1$ & $320.6 \pm 80.9$ & $\begin{array}{c}* 0.041>2 \\
* * 0.0391>3 \\
* * * 0.1892=3\end{array}$ \\
\hline
\end{tabular}

* (Paired sample $t$ test) between baseline and after one month treatment values.

** (Student $t$ test) between baseline and control group

*** (Student $t$ test) between control group an done month after treatment values.

The mean age of study and control groups were $12.4 \pm$ 3.5 years and $11.5 \pm 4.1$ years, respectively. The groups were similar in terms of age and gender $(\mathrm{p}=0.48, \mathrm{p}=$ 0.74) (Table 1).

Sub-foveal choroidal thickness was $364.1 \pm 63.8$ $\mu \mathrm{m}$ in the allergic conjunctivitis group; the first-month mean values after the treatment were $333.5 \pm 52.1 \mu \mathrm{m}$. Sub-foveal choroidal thickness means value in the control group was $320.6 \pm 80.9$. There was a statistically significant decrease in mean ChT value after treatment of allergic conjunctivitis patients (paired sample t-test; $p=0.04$ ) and there was a significant difference between baseline ChT values of allergic conjunctivitis group and control group (student t-test; $p=0.039$ ). There was no significant difference between one-month values after treatment and mean values of the control group (student t-test; $\mathrm{p}=0.189$ ) (Table 2). When the choroidal thickness of children and adolescents with allergic conjunctivitis were compared according to gender, the choroidal thickness of boys was found to be higher than girls. However, this difference was not statistically significant $(\mathrm{p}=0.357)$.

\section{DISCUSSION AND CONCLUSION}

In this study, we investigated whether there is any difference in terms of choroidal thickness in children and adolescents with acute allergic conjunctivitis. We also examined the effect of conservative and medical treatment on choroidal thickness in children with allergic conjunctivitis. The baseline ChT values of the study group were significantly higher than the control group. And there was a statistically significant decrease in ChT of children and adolescents with allergic conjunctivitis after treatment with topical antihistamine agents.

In a study conducted by Yenigun et al. evaluated whether there were any differences in choroidal thick- ness between allergic rhinitis patients and healthy controls. The mean sub-foveal choroidal thickness was $367.49 \pm 92.73 \mu \mathrm{m}$ in patients with allergic rhinitis and the mean sub-foveal choroidal thickness in patients without allergic rhinitis was $327.62 \pm 72.39 \mu \mathrm{m}$. In parallel with our study, they found this difference was statistically significant (18). Previous studies indicated that choroidal alterations were determined in several ocular or systemic diseases associated with inflammation. In two adult patients with posterior sclerosis, choroidal thickness measured by OCT was found thickened in the active phase of the disorder and thinned after treatment. The authors suggested that recurrent inflammation of the sclera could induce atrophic changes. In two different studies from the Far East, sub-foveal choroidal thickness measured by EDI-OCT of patients with posterior uveitis due to Behçet's disease was increased in the acute phase of the disease and decreased after the relief of the acute phase. They showed sub-foveal choroidal thickness was correlated with retinal vascular leakage revealed by fluorescein angiography (12, 19). In a case report presents a patient diagnosed with sarcoidosis and having unilateral, multifocal choroidal granuloma, it was revealed that choroidal thickness decreased by steroid treatment (20). In another study examining choroidal changes in toxoplasma cases with retino-choroidal lesions, it was found that choroidal thickness was higher in the acute phase of the disease and was determined normally in the follow-up (21).

Another finding in our study was that boys had higher choroidal thickness than girls. However, this difference was not statistically significant. In a study from Denmark, the sub-foveal choroidal thickness of 1323 healthy children aged 11 to 12 years was measured by using EDI-OCT. It has been determined that the sub-foveal choroidal thickness was higher in fe- 
males than in males but the difference wasn't significant (22).

In our study, the sample size was small, so studies with a larger sample are needed to confirm our findings and to fully clarify the mechanism of increased choroidal thickness with allergic conjunctivitis. To track allergic conjunctivitis activity and evaluate the effectiveness of the treatment, choroidal thickness measures can be utilized.
Abbreviations
ChT - choroidal thickness
CSCR - central serous chorioretinopathy
CNS - central nervous system

SD-OCT - Spectral Optical Coherence Tomography

EDI OCT - enhanced depth imaging spectral-domain optical coherence tomography

\section{Acknowledgment: None}

Conflict of Interests: The authors declare that there are no conflicts of interest related to this article.

Funding: This research did not receive any specific grant from funding agencies in the public, commercial, or not-for-profit sectors.

Authorship Statement: TA, DA wrote the manuscript. TA, MY designed the study, TA, DA and MY contributed to data collection. TA and DA performed the statistical analysis and interpretation of the results. All authors read and approved the final manuscript.

\section{Licensing}

This work is licensed under a Creative Commons Attribution 4.0 International (CC BY 4.0) License.

\section{Sažetak}

\section{UTICAJ ALERGIJSKOG KONJUKTIVITISA NA DEBLJINU HOROIDEE}

\begin{abstract}
Cilj: Ispitati efekte alergijskog konjunktivitisa i njegovog lečenja korišćenjem topikalnih antihistaminskih lekova na debljinu horoidee (ChT).

Metode: U istraživanju je učestvovalo 30 dece i adolescenata sa alergijskim konjunktivitisom kao i 30 zdravih kontrola. Kriterijumi za uključivanje pacijenata u istraživanje bili su najbolja korigovana vidna oštrina 20/20 ili bolje, normalan intraokularni pritisak (IOP), i odsustvo sistemskih ili drugih očnih bolesti osim alergijskog konjunktivitisa. Zdrave kontrole su podrazumevale decu i adolescente bez očnih ili hroničnih sistemskih bolesti i koji su imali najbolju korigovanu vidnu oštrinu 20/20 ili bolje i normalan IOP. ChT je merena pomocu EDI-OCT (Enhanced Depth Imaging Optical Coherence Tomography) pre i posle tretmana antihistaminicima.
\end{abstract}

Ayyildiz Taha, ${ }^{1}$ Yilmaz Mevlut, ${ }^{2}$ Ayyildiz Didem ${ }^{3}$

${ }^{1}$ Kırsehir Ahi Evran University, Faculty of Medicine, Ophthalmology Department, Kırsehir, Turkey

${ }^{2}$ Turkey Kırsehir Ahi Evran University, Faculty of Medicine, Ophthalmology Department, Kirsehir, Turkey

${ }^{3}$ Kirsehir Ahi Evran University, Training and Research Hospital, Child and Adolescent Psychiatry Department, Kirsehir, Turkey

Rezultati: Srednja vrednost subfovealne horoidalne debljine bila je $364.1 \pm 63.8 \mu \mathrm{m}$ u grupi sa alergijskim konjunktivitisom, a vrednost nakon prvog me-

\section{REFERENCES}

1. Kañski J, Bowling B.Clin Ophthalmol.Elsevier Urban \& Partner, Wroc'aw 2013, 1:40.

2. Read SA, Collins MJ, Vincent SJ, Alonso-Caneiro D.Choroidal thickness in childhood. Invest Ophthalmol Vis Sci.2013; 54(5): 3586-93. seca tretmana bila je $333.5 \pm 52.1 \mu \mathrm{m}$. Srednja vrednost subfovealne horoidalne debljine u kontrolnoj grupi bila je $320.6 \pm 80.9 \mu \mathrm{m}$. Došlo je do značajnog smanjenja ChT nakon lečenja pacijenata sa alergijskim konjunktivitisom i postojala je statistički značajna razlika u odnosu na početne vrednosti ChT između grupe sa alergijskim konjunktivitisom i kontrolne grupe. Nije bilo značajne razlike između srednjih vrednosti ChT nakon jednomesečnog lečenja i srednjih vrednosti kontrolne grupe.

Zaključak: Naši rezultati pokazuju da ChT može porasti kod pacijenata sa alergijskim konjunktivitisom i ponovo može postati normalna usled lokalnog lečenja antihistaminicima. Kako bi se podržalo to da horoidalna debljina bude marker za dijagnozu i praćenje alergijskog konjunktivitisa, dodatna istraživanja sa većim uzorcima i longitudinalne studije su potrebne.

Ključne reči: alergijski konjunktivitis, antihistamin, horoidalna debljina, topikalne kapi za oči, lečenje.

3. Park K-A, Oh SY.Choroidal thickness in healthy children. Retina.2013; 33(9): 1971-6.

4. Read SA, Collins MJ, Vincent SJ, Alonso-Caneiro D.Choroidal thickness in myopic and nonmyopic children assessed with enhanced depth imaging optical coherence tomography. Invest Ophthalmol Vis Sci.2013; 54(12): 7578-86. 
5. Zha Y, Zhuang J, Du Y, Cai J, Zheng H.Evaluation of peripapillary choroidal distribution in children by enhanced depth imaging optical coherence tomography. BMC ophthalmol. 2018; 18(1): 173.

6. Imamura Y, Fujiwara T, Margolis R, Spaide RF.Enhanced depth imaging optical coherence tomography of the choroid in central serous chorioretinopathy. Retina.2009; 29(10): 1469-73.

7. Chen G, Tzekov R, Li W, Jiang F, Mao S, Tong Y. Subfoveal choroidal thickness in central serous chorioretinopathy: a meta-analysis. PloS one.2017; 12(1):e0169152.

8. Regatieri CV, Novais EA, Branchini L, Adhi M, Cole ED, Louzada R, et al.Choroidal thickness in older patients with central serous chorioretinopathy. Int J Retina Vitreous. 2016; 2(1):22.

9. Maruko I, Iida T, Sugano Y, Ojima A, Sekiryu T.Subfoveal choroidal thickness in fellow eyes of patients with central serous chorioretinopathy. Retina.2011; 31(8): 1603-8.

10. Ağın A, Kadayıfçılar S, Sönmez H, Baytaroğlu A, Demir S, Sağ E, et al. Evaluation of choroidal thickness, choroidal vascularity index and peripapillary retinal nerve fiber layer in patients with Juvenile systemic lupus erythematosus. Lupus. 2019; 28(1): 44-50.

11. Onal IK, Yuksel E, Bayrakceken K, Demir MM, Karaca EE, Ibis M, et al. Measurement and clinical implications of choroidal thickness in patients with inflammatory bowel disease. Arq Bras Oftalmol. 2015; 78(5): 278-82.

12. Ishikawa S, Taguchi M, Muraoka T, Sakurai Y, Kanda $\mathrm{T}$, Takeuchi M.Changes in subfoveal choroidal thickness associated with uveitis activity in patients with Behcet's disease. Br J Ophthalmol.2014; 98(11): 1508-13.

13. Kola M, Kalkisim A, Karkucak M, Turk A, Capkin E, Can I, et al. Evaluation of choroidal thickness in ankylosing spondylitis using optical coherence tomography. Ocul Immunol Inflamm. 2014; 22(6): 434-8.
14. Huang D, Swanson EA, Lin CP, Schuman JS, Stinson WG, Chang W, et al. Optical coherence tomography. Science.1991; 254(5035): 1178-81.

15. Spaide RF, Koizumi H, Pozonni MC. Enhanced depth imaging spectral-domain optical coherence tomography. Am J Ophthalmol. 2008; 146(4): 496-500.

16. Tan CS, Ouyang Y, Ruiz H, Sadda SR.Diurnal variation of choroidal thickness in normal, healthy subjects measured by spectral domain optical coherence tomography. Invest Ophthalmol Vis Sci. 2012; 53(1): 261-6.

17. Rahman W, Chen FK, Yeoh J, Patel P, Tufail A, Da Cruz L. Repeatability of manual subfoveal choroidal thickness measurements in healthy subjects using the technique of enhanced depth imaging optical coherence tomography. Invest Ophthalmol Vis Sci. 2011; 52(5): 2267-71.

18. Yenigun A, Elbay A, Dogan R, Ozturan O, Ozdemir MH.The effect of allergic rhinitis with positive skin prick test on choroidal thickness. Eur Arch Otorhinolaryngol. 2017; 274(6): 2477-81.

19. Kim M, Kim H, Kwon HJ, Kim SS, Koh HJ, Lee SC. Choroidal thickness in Behcet's uveitis: an enhanced depth imaging-optical coherence tomography and its association with angiographic changes. Invest Ophthalmol Vis Sci. 2013; 54(9): 6033-9.

20. Modi YS, Epstein A, Bhaleeya S, Harbour JW, Albini T.Multimodal imaging of sarcoid choroidal granulomas. J Ophthalmic Inflamm Infect.2013; 3(1):58.

21. Goldenberg D, Goldstein M, Loewenstein A, Habot-Wilner Z.Vitreal, retinal, and choroidal findings in active and scarred toxoplasmosis lesions: a prospective study by spectral-domain optical coherence tomography. Graefes Arch Clin Exp Ophthalmol. 2013; 251(8): 2037-45.

22. Li XQ, Munkholm A, Larsen M, Munch IC.Choroidal thickness in relation to birth parameters in 11-to 12-year-old children: the Copenhagen Child Cohort 2000 Eye Study. Invest Ophthalmol Vis Sci. 2015; 56(1): 617-24.

\section{Correspondence to/Autor za korespondenciju}

Mevlut Yilmaz, Assistant Professor

Turkey Kurşehir Ahi Evran University Faculty of Medicine, Ophthalmology Department, Turkey

Email: drmevlutyilmaz@gmail.com

Telephone: 00905557720767 